\title{
Assessment of serotonergic system in formation of memory and learning
}

\author{
J. C. da Silva ${ }^{a}$, C. A. M. Amorim ${ }^{a}$, G. P. Rodrigues ${ }^{a}$, J. Dal Pai ${ }^{b}$, L. I. Zambrano ${ }^{c}$ and \\ E. M. Trindade Filho ${ }^{a *}$
}

${ }^{a}$ Laboratório de Neurociência e Comportamento, Núcleo de Ciências Biológicas - NUCIB, Universidade Estadual de Ciências da Saúde de Alagoas - UNCISAL, Rua Doutor Jorge de Lima, 113, Trapiche da Barra, CEP 57010-382, Maceió, AL, Brazil

bUniversidade Nove de Julho - UNINOVE, Rua Vergueiro, 235/249, Liberdade, CEP 01504-000, São Paulo, SP, Brazil ${ }^{\mathrm{c}}$ Facultad de Ciencias Medicas, Universidad Nacional Autónoma de Honduras, Edificio E1, 2da Planta, Suyapa Ciudad Universitaria Blvd, 33012, Tegucigalpa, Honduras

*e-mail: emtfilho@gmail.com

Received: October 23, 2016 - Accepted: April 25, 2017 - Distributed: October 31, 2018

\begin{abstract}
We evaluated the involvement of the serotonergic system on memory formation and learning processes in healthy adults Wistar rats. Fifty-seven rats of 5 groups had one serotonergic nuclei damaged by an electric current. Electrolytic lesion was carried out using a continuous current of $2 \mathrm{~mA}$ during two seconds by stereotactic surgery. Animals were submitted to learning and memory tests. Rats presented different responses in the memory tests depending on the serotonergic nucleus involved. Both explicit and implicit memory may be affected after lesion although some groups showed significant difference and others did not. A damage in the serotonergic nucleus was able to cause impairment in the memory of Wistar. The formation of implicit and explicit memory is impaired after injury in some serotonergic nuclei.
\end{abstract}

Keywords: memory, rat, serotonin, learning, neuronal plasticity.

\section{Avaliação do sistema serotonérgico na formação de memória e aprendizagem}

\section{Resumo}

Avaliar a participação do sistema serotoninérgico em processos de formação de memória e aprendizagem em ratos Wistar adultos saudáveis. Cinquenta e sete ratos de 5 grupos tinham um núcleo serotoninérgico danificado por uma corrente elétrica. A lesão eletrolítica foi realizada utilizando uma corrente contínua de $2 \mathrm{~mA}$ durante dois segundos por cirurgia estereotáxica. Os animais foram submetidos a testes de aprendizagem e memória. Os ratos apresentaram respostas diferentes nos testes de memória, dependendo do núcleo serotoninérgica envolvido. A memória explícita e implícita pode ser afetada após a lesão, embora alguns grupos apresentaram diferença significativa e outros não. A lesão no núcleo serotoninérgico foi capaz de causar danos na memória de Wistar. A formação da memória implícita e explícita é prejudicada após a lesão em alguns núcleos serotoninérgicos.

Palavras-chaves: memória, rato, serotonina, aprendizagem, plasticidade neuronal.

\section{Introduction}

The main subcortical input to the hippocampal region comes from fimbria-fornix pathway, which is involved in explicit and implicit memory processes (Guillazo-Blanch et al., 2002; Morrell, 2011). The hippocampi are often reported as the generator of rhythms related with learning and memory due to its involvement with neuronal plasticity known as short- and long-term potentiation (Beierlein et al., 2003; Ghaderi et al., 2016; Dittman et al., 2000; Sheikhzadeh et al., 2015). Facilitation of synaptic plasticity may occur by repeated activations and increase of neurotransmitter release, either by saturating the calcium buffer or increasing its concentration in the presynaptic terminal of the neuron. Studies show that plasticity of nervous system may occur throughout life and appears to be widespread in areas such as hippocampus, several cortical areas and thalamic-cingulate pathway (Sheikhzadeh et al., 2015; Emptage et al., 2001; Shyu and Vogt, 2009; Nudo, 2006). In this paper, we describe the involvement of the serotonergic system with memory formation and learning processes in the rat.

\section{Material and Methods}

Fifty-seven adult male Wistar rats weighing between 220-250 grams were housed under environmentally controlled conditions (light/dark cycle with lights on from 07:00 to 19:00 hours, $22-24.8^{\circ} \mathrm{C}$ ) and permitted 
free access to food and water throughout the experiment. The procedures involving animals and their care followed Institution's guidelines, which comply with the international Ethical Guidelines for Biomedical Research (Howard-Jones, 1985).

\subsection{Experimental procedures}

Experimental animals $(\mathrm{n}=50)$ were divided into 5 groups according to serotonergic nucleus included in this research (B5, B6, B7, B8 and B9). Rats were anesthetized with a mixture of ketamine $90 \mathrm{mg} / \mathrm{kg}$, and xylazine $12 \mathrm{mg} / \mathrm{kg}$ (i.p.), after exposure of the skull, bipolar electrodes (stimulating) stainless steel were implanted into one of the serotonergic nuclei using stereotactic surgery according to Paxinos and Watson (1997) atlas. Each group of ten animals received injury in a specific serotonergic nucleus. Damage was done by continuous electric current of $2 \mathrm{~mA}$ during $2 \mathrm{sec}$ using a stimulator device/lesador (EFF 341 - Insight, Brazil).

After seven days to recovery animals were evaluated through the classic maze with food and Morris water maze to assess spatial memory and learning. The time spent for each animal to complete the tests was measure in seconds. All tests were performed in 3 consecutive days and each animal was assessed individually.

\subsection{Statistical analysis}

Data are presented as mean $(\mathrm{m}) \pm$ standard deviation (SD). The comparison of the time (in second) spent for the animal to reach the food on the $1^{\text {st }}$ compared to the $3^{\text {rd }}$ day (same group) was executed using the Paired T Test. Differences were considered statistically significant when the $p$-value was $\leq 0.05$. GraphPad Software Prism 4.0, San Diego, USA, was used to analyze the data.

\section{Results}

Our findings showed that the time spent for the rat to reach the food on the classic maze and the platform in the Morris water maze tests were different among groups. Animals who suffered lesion in the B5 nucleus showed improvement in implicit and explicit memory tests when the $1^{\text {st }}$ and $3^{\text {rd }}$ day was compared (as shown in Table 1).

B8 group of rats also had a significant reduction in the time spent to reach the objective in the explicit memory tests, showing an improvement in its execution. Concerning the implicit memory test, B7 and B9 groups spent more time to have it completed, but statistical analysis was not significant. On the other hand, animals who suffered damage in B6 and B8 nuclei showed tendency to reduce the time to complete the implicit memory test. In the explicit memory test, animals with lesion in B6 nucleus and also those with B7 and B9 nuclei damaged, showed a tendency to a improvement in the test, although results did not show significance.

\section{Discussion}

The understanding of the relationship between declarative (explicit) and nondeclarative (implicit) memory systems would be a great advance to neurobiology and behavioral neurosciences (Rampersaud et al., 2012; Weiss and Disterhoft, 2015). In this work we analyzed implicit and explicit memory of rats submitted to lesions in serotonergic groups (B5, B6, B7, B8 and B9) using classic maze with food and Morris water maze. Although we expected an impairment of both memories (declarative and nondeclarative), in the most part of the nuclei damaged, results showed that lesion into serotonergic nucleus of rats induced to different responses, depending on the nucleus injured.

Turnbull et al. (1994) showed that lesions in fornix, fimbria, as well as on medial septal nuclei, might affect theta rhythm in the hippocampus and also memory impairment. On the other hand, after stimulating electrically the hippocampus in rats with the fornix damaged, researchers found normal hippocampal theta rhythm and also improvement in memory (Turnbull et al., 1994). Researchers have observed that patients who suffered a lesion, or received stimulation in a specific area of the brain show different responses after that (Zacks et al., 2016; Lecce et al., 2015; Mulholland et al., 1979; Pillon et al., 1987; Benke et al., 2003). A study made with patients after they had thalamotomy surgery, did not show reduction in cognitive level when memory tests were applied. Whereas, stimulation into the thalamus showed increased responses in memory tests. Lesion on the left side of the thalamus showed a decrease in the number of correct responses given by the rats when evaluated by a listening test (Prasad et al., 2017). Parkinsonian patients submitted to thalamotomy were tested to investigate the verbal memory and did not present cognitive deficit. In this paper authors showed that high-intensity stimulation in the left side of the thalamus

Table 1. Results of the classic maze and platform in the Morris water maze to learning and memory.

\begin{tabular}{|c|c|c|c|c|c|c|}
\hline \multirow{2}{*}{ Groups } & \multicolumn{3}{|c|}{ Implicit memory $(\mathrm{m} \pm \mathrm{SD})$} & \multicolumn{3}{|c|}{ Explicit memory $(m \pm S D)$} \\
\hline & 1st day & 3rd day & P value & 1st day & 3rd day & P value \\
\hline B5 & $1930.8 \pm 899.61$ & $1165.4 \pm 512.86$ & $\mathrm{P}<0.05$ & $65.6 \pm 21.56$ & $13.6 \pm 13.51$ & $\mathrm{P}<0.05$ \\
\hline B6 & $996.3 \pm 805.91$ & $811.2 \pm 1078.43$ & - & $22.62 \pm 15.24$ & $16.00 \pm 9.49$ & - \\
\hline B7 & $1139.46 \pm 807.66$ & $1271.69 \pm 1031.93$ & - & $19.39 \pm 9.19$ & $12.38 \pm 5.25$ & - \\
\hline B8 & $1413.7 \pm 565.86$ & $1343.6 \pm 609.92$ & - & $65.6 \pm 21.56$ & $13.6 \pm 13.51$ & $\mathrm{P}<0.05$ \\
\hline B9 & $547.5 \pm 486.06$ & $1594.1 \pm 1215.16$ & - & $27.36 \pm 10.90$ & $10.53 \pm 4.87$ & - \\
\hline
\end{tabular}

Mean \pm Standard deviation: $\mathrm{m} \pm \mathrm{SD}$; 1st: First; 3rd: Third. 
decreased the performance into the test (Wester and Hugahl, 1997). In our work we saw that rats who had a specific serotonergic group damaged (B5-implicit and explicit or B8- explicit only) showed a better response in these memory tests, which may not be related to an improvement in this type of memory. Other groups (B6 and B8) for implicit memory test and (B6, B7 and B9) for explicit memory test showed a tendency to improve its execution, but results was not significant. On the other hand, animal with B7 and B9 serotonergic nuclei damaged, showed a tendency to worse its response in implicit test, but results did not show significance between the $1^{\text {st }}$ and $3^{\text {rd }}$ day of execution. Many disorders seen in patients without an effective treatment have encouraged basic researchers to look for novel approaches in the use of animal models of cognitive impairment, which is important for the understanding of its physiopathology and also the development of new therapies (Gornicka-Pawlak et al., 2015; Dalrymple-Alford et al., 2015; Huijgen and Samson, 2015; Danet et al., 2015). This work suggests that serotonergic nuclei together with Papez's circuit might be an important target in the study and understanding of the mechanisms involved in memory impairment. These data represent an approach to study the paradigms of mechanisms involved in the damage of serotonergic nuclei. Additional studies are needed for further understanding of the neurophysiology of serotonergic system and its relationship with Papez's cirtuit.

\section{Acknowledgements}

The authors would like to thanks the Fundação de Amparo à Pesquisa do Estado de Alagoas - FAPEAL. This work was supported by grants from the from FAPEAL (Brazil) and C.A.M Amorim was fellow.

\section{References}

BEIERLEIN, M., GIBSON, J.R. and CONNORS, B.W., 2003. Two dynamically distinct inhibitory networks in layer 4 of the neocortex. Journal of Neurophysiology, vol. 90, no. 5, pp. 29873000. PMid:12815025. http://dx.doi.org/10.1152/jn.00283.2003.

BENKE, T., DELAZER, M., BARTHA, L. and AUER, A., 2003. Basal ganglia lesions and the theory of fronto-subcortical loops: neuropsychological findings in two patients with left caudate lesions. Neurocase, vol. 9, no. 1, pp. 70-85. PMid:16210227. http://dx.doi.org/10.1076/neur.9.1.70.14374.

DALRYMPLE-ALFORD, J.C., HARLAND, B., LOUKAVENKO, E.A., PERRY, B., MERCER, S., COLLINGS, D.A., ULRICH, K., ABRAHAM, W.C., MCNAUGHTON, N. and WOLFF, M., 2015. Anterior thalamic nuclei lesions and recovery of funcition: Relevance to cognitive thalamus. Neuroscience and Biobehavioral Reviews, vol. 54, pp. 145-160. PMid:25637779. http://dx.doi. org/10.1016/j.neubiorev.2014.12.007.

DANET, L., BARBEAU, E.J., EUSTACHE, P., PLANTON, M., RAPOSO, N., SIBON, I., ALBUCHER, J.F., BONNEVILLE, F., PERAN, P. and PARIENTE, J., 2015. Thalamic amnesia after infarct: the role of the mammillothalamic tract and mediodorsal nucleus. Neurology, vol. 85, no. 24, pp. 2107-2115. PMid:26567269. http://dx.doi.org/10.1212/WNL.0000000000002226.
DITTMAN, J.S., KREITZER, A.C. and REGEHR, W.G., 2000. Interplay between facilitation, depression, and residual calcium at three presynaptic terminals. The Journal of Neuroscience, vol. 20, no. 4, pp. 1374-1385. PMid:10662828.

EMPTAGE, N.J., REID, C.A. and FINE, A., 2001. Calcium stores in hippocampal synaptic boutons mediate short-term plasticity, store-operated $\mathrm{Ca} 2+$ entry, and spontaneous transmitter release. Neuron, vol. 29, no. 1, pp. 197-208. PMid:11182091. http://dx.doi. org/10.1016/S0896-6273(01)00190-8.

GHADERI, M., REZAYOF, A., VOUSOOGHI, N. and ZARRINDAST, M.R., 2016. Dorsal hippocampal NMDA receptors mediate the interactive effects of arachidonylcyclopropylamide and MDMA/ecstasy on memory retrieval in rats. Progress in NeuroPsychopharmacology \& Biological Psychiatry, vol. 66, pp. 41-47. PMid:26612394. http://dx.doi.org/10.1016/j.pnpbp.2015.11.008.

GORNICKA-PAWLAK, E., JANOWSKI, M., JABLONSKA, A., SYPECKA, J. and DOMANSKA-JANIK, K., 2015. Complex assessment of distinct cognitive impairments following ouabain injection into the rat dorsoloateral striatum. Behavioural Brain Research, vol. 289, pp. 133-140. PMid:25845737. http://dx.doi. org/10.1016/j.bbr.2015.03.061.

GUILLAZO-BLANCH, G., NADAL, R., VALE-MARTÍNEZ,A., MARTÍ-NICOLOVIUS, M., ARÉVALO, R. and MORGADOBERNAL, I., 2002. Effects of fimbria lesions on trace two-way active avoidance acquisition and retention in rats. Neurobiology of Learning and Memory, vol. 78, no. 2, pp. 406-425. PMid:12431426. http://dx.doi.org/10.1006/nlme.2002.4073.

HOWARD-JONES, N., 1985. A CIOMS ethical code for animal experimentation. WHO Chronicle, vol. 39, no. 2, pp. 51-56. PMid:4090462.

HUIJGEN, J. and SAMSON, S., 2015. The hippocampus: a central node a large-scale brain network for memory. Revue Neurologique, vol. 171, no. 3, pp. 204-216. PMid:25770921. http://dx.doi.org/10.1016/j.neurol.2015.01.557.

LECCE, F., ROTONDARO, F., BONNÌ, S., CARLESIMO, A., THIEBAUT DE SCHOTTEN, M., TOMAIUOLO, F. and DORICCHI, F., 2015. Cingulate neglect in humans: disruption of contralesional reward learning in right brain damage. Cortex, vol. 62, pp. 73-88. PMid:25239855. http://dx.doi.org/10.1016/j. cortex.2014.08.008.

MORRELL, M.J., 2011. Responsive cortical stimulation for the treatment of medically intractable partial epilepsy. Neurology, vol. 77, no. 13, pp. 1295-1304. PMid:21917777. http://dx.doi. org/10.1212/WNL.0b013e3182302056.

MULHOLLAND, T., MCLAUGHLIN, T. and BENSON, F., 1979. Quantification of the human orienting response to another human: lesioned and psychiatric patients compared to normals. The Journal of Nervous and Mental Disease, vol. 167, no. 3, pp. 166-170. PMid:438785. http://dx.doi.org/10.1097/00005053197903000-00005

NUDO, R.J., 2006. Plasticity. NeuroRx, vol. 3, no. 4, pp. 420-427. PMid:17012055. http://dx.doi.org/10.1016/j.nurx.2006.07.006.

PAXINOS, G. and WATSON, C., 1997. The rat brain in stereotactic coordinates. Sidney: Academic Press.

PILLON, B., BAKCHINE, S. and LHERMITTE, F., 1987. Alexia without agraphia in a left-handed patient with a right occipital lesion. Archives of Neurology, vol. 44, no. 12, pp. 1257-1262. PMid:3675259. http://dx.doi.org/10.1001/archneur.1987.00520240039009. 
PRASAD, J.A., ABELA, A.R. and CHUDASAMA, Y., 2017. Midline thalamic reuniens lesions improve executive behaviors. Neuroscience, vol. 345, pp. 77-88. PMid:26868974. http://dx.doi. org/10.1016/j.neuroscience.2016.01.071.

RAMPERSAUD, N., HARKAVYI, A., GIORDANO, G., LEVER, R., WHITTON, J. and WHITTON, P.S., 2012. Exendin-4 reverses biochemical and behavioral deficits in a pre-motor rodent model of Parkinson's disease with combined noradrenergic and serotonergic lesions. Neuropeptides, vol. 46, no. 5, pp. 183-193. PMid:22921965. http://dx.doi.org/10.1016/j.npep.2012.07.004.

SHEIKHZADEH, F., ETEMAD, A., KHOSHGHADAM, S., ASL, N.A. and ZARE, P., 2015. Hippocampal BDNF content in response to short- and long-term exercise. Neurological Sciences, vol. 36, no. 7, pp. 1163-1166. PMid:25860428. http://dx.doi. org/10.1007/s10072-015-2208-z.

SHYU, B.C. and VOGT, B.A., 2009. Short-term synaptic plasticity in the nociceptive thalamic-anterior cingulate pathway. Molecular Pain, vol. 5, pp. 51. PMid:19732417. http://dx.doi. org/10.1186/1744-8069-5-51
TURNBULL, J., JIANG, F. and RACINE, R., 1994. Hippocampal stimulation of fornical-sesioned rats improves working memory. The Canadian Journal of Neurological Sciences, vol. 21, no. 2, pp. 100-103. PMid:8087733. http://dx.doi.org/10.1017/ S0317167100049003.

WEISS, C. and DISTERHOFT, J.F., 2015. The impact of hippocampal lesions on trace-eyeblink conditioning and forebrain-cerebellar interactions. Behavioral Neuroscience, vol. 129, no. 4, pp. 512522. PMid:26214216. http://dx.doi.org/10.1037/bne0000061.

WESTER, K. and HUGAHL, K., 1997. Thalamotomy and thalamic stimulation: effects on cognition. Stereotactic and Functional Neurosurgery, vol. 69, no. 1-4 Pt 2, pp. 80-85. PMid:9711738.

ZACKS, J.M., KURBY, C.A., LANDAZABAL, C.S., KRUEGER, F. and GRAFMAN, J., 2016. Effects of penetrating traumatic brain injury on event segmentation and memory. Cortex, vol. 74, pp. 233-246. PMid:26704077. http://dx.doi.org/10.1016/j. cortex.2015.11.002. 